\title{
Embodied Transcendence: The Buddha's Body in the Pāli Nikāyas
}

\author{
Eviatar Shulman
}

check for

updates

Citation: Shulman, Eviatar. 2021. Embodied Transcendence: The

Buddha's Body in the Pāli Nikāyas. Religions 12: 179. https://doi.org/ 10.3390/rel12030179

Academic Editor: Brooke Schedneck

Received: 26 January 2021

Accepted: 2 March 2021

Published: 9 March 2021

Publisher's Note: MDPI stays neutral with regard to jurisdictional claims in published maps and institutional affiliations.

Copyright: (c) 2021 by the author. Licensee MDPI, Basel, Switzerland. This article is an open access article distributed under the terms and conditions of the Creative Commons Attribution (CC BY) license (https:/ / creativecommons.org/licenses/by/ $4.0 /)$.
The Department of Comparative Religion and the Department of Asian Studies, The Hebrew University of Jerusalem, Jerusalem 91905, Israel; eviatar.shulman@mail.huji.ac.il

Abstract: This article reassesses the role of the body in advanced meditation as it is presented in the early Buddhist Pāli discourses, showing that certain theorizations of liberation held that it contained a marked corporeal element. The article also reflects upon the understanding of the Buddha's body in this textual corpus, and demonstrates that for important strands of the early tradition, the Buddha's liberation was thought to manifest in his body, so that liberation impacted his physical presence and the quality of his movement. There are also marked metaphysical dimensions to the Buddha's body, so that its nature transcends the material. Common approaches that take liberation to be a purely psychological transformation thus ignore important aspects of the traditional understanding, which also directs us to think of a plurality of approaches to liberation.

Keywords: body; early Buddhism; liberation; Buddha

\section{Introduction}

What is a body according to the Buddha, and is it related to realization and awakening? How did the early Buddhists understand the Buddha's body, and how did they conceive of the relation between his body and mind? The more common interpretations of these issues emphasize the mental and psychological aspects of liberation, so that the body is not deemed essential to awakening and is considered tangential at best. ${ }^{1}$ The body, as the Buddha may repeat in different contexts, is to be discarded, as are the other senses, so that the Buddhist transformation is mainly one of the mind or of consciousness. ${ }^{2}$ Liberation can even be understood as a complete transcendence of the bodily and the mental, of every experience that has any formal aspect, so that what remains is completely abstract, purified to the extreme, beyond the realms of language. ${ }^{3}$ Possibly, such an experience may relate to a deep, comprehensive meditative state, or to a discovery of the lustrous nature of consciousness. ${ }^{4}$ Yet it is rare to find an interpretation of enlightenment that highlights

1 That this approach continues to be influential, beyond many of the classic studies referred to below, can be seen is such studies as Anālayo (2012, p. 307), who emphasizes "liberation of mind and liberation by wisdom"; see also in the recent, in-depth study of $j h \bar{a} n a$ by Arbel (2017).

2 As in SN IV.15 (Discourse \#24): "I will teach you a truth for the abandoning of everything ... The eye should be abandoned ... The ear ... the body should be abandoned, bodily sensations should be abandoned, body-consciousness should be abandoned, body contact [the meeting of the body, the sensation and the consciousness] should be abandoned, feelings that arise dependent on body contact, whether pleasant, painful or neither pleasant nor painful, should be abandoned.sabbapahānāya vo bhikkhave dhammam dessissāmi ... cakkhum, bhikkhave, pahātabbam ... sotam pahätabbam

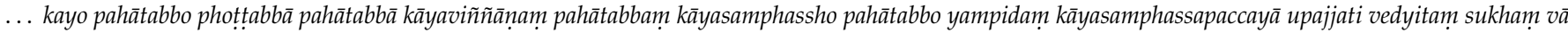
dukkham vā adukkhamasukkham vā tampi pahātabbạm.All translations from Pāli are my own. Pāli sources are adapted from the editions of the Pāli Text Society and the Vipassanā Research Institute, and quoted according to the former's page numbers.

3 As for example in the Aggivacchagotta-sutta of the Majjhima Nikāya (MN), in which the Buddha describes his liberation as being completely freed of the five aggregates, so that it cannot be said whether after his death he will be reborn, not-reborn, both or neither. He then offers the simile of the fire, which after being extinguished cannot be said to have gone in any of the four cardinal directions. This presentation also relates to the classic formulation that distinguishes between nibbāna with or without remainder (sa-upādi-sesa/nir-upādi-sesa), that is with or without the presence of the aggregates, as discussed by Harvey (1995, chp. 11).

4 As in the deep meditative state of sañ $\tilde{a}$-vedayita-nirodha ("cessation of perception and feeling"), or in one of the four "formless attainments", arūpya-samāpatti, that lead to it. See the description of these states in, e.g., the MN's Anupada-sutta (no. 111), at MN III.27-28, and the discussion of nirodha in Harvey (1995, chp. 11). For an interpretation that emphasizes luminosity, see the concluding verses of the Kevaddha-sutta (DN 11, I.223), or the verses in Udāna 8.1 or 8.3., as well as the Discussion in Harvey (1995, chp. 12). 
its corporeal, physical, and bodily sides, which may lead us to ask what the embodied dimensions of transcendence may include, as perplexing as such a formulation may appear.

The question regarding the bodily aspects of liberation is perhaps deeper than we suspect. What do we expect "liberation" to consist of? While modern (or modernist) approaches tend to locate awakening within experience and see it as a psychological transformation, ${ }^{5}$ if the concept of 'liberation' is taken seriously, it should transcend any conditioned, impermanent and compounded artifact—ideas that early Buddhism employs forcefully to characterize the nature of experience, as in the concepts of anicca (impermanence), paticcasamuppāda (dependent-origination), and sankkhata (conditioning). While many of the early traditional interpretations are indeed faithful to this rather radical approach, ${ }^{6}$ we may expect there also be a dimension in which "liberation" relates to the experience, in the body and the mind, of people who lived to tell the tale; otherwise, we would have never heard of it. Once liberation is not a purely transcendent and abstract event, there would naturally be different types of liberation in both practice and theory, some of which would have a more pronounced corporeal dimension. Indeed, there is not one liberation in the Nikāyas and there are conflicting presentations of its contents, as well as of the manner in which it may be generated-the path. "Liberation" as a concept can refer to different meditative states, such as the "signless liberation of mind" (animitta cetovimutti), the "boundless liberation of mind" (appamānā cetovimutti) that relates to the Brahmavihāra-meditations, the "liberation of mind in nothingness" (akiñcañ $\tilde{a} \bar{a}$ cetovimutti) or the "emptiness liberation of mind" (suñ̃natā cetovimutti), ${ }^{7}$ while we also find a classic list of 8 liberations, ${ }^{8}$ and the Nikāyas can even speak of a "mistaken liberation" (micchā vimutti). ${ }^{9}$ We may also recall the classic, scholarly debate between the intellectualist and mystical approaches to liberation, that is between liberation as the product of meditation or of philosophical reflection. ${ }^{10}$

Rather than trying to solve the debate on the nature of liberation, or to define a clear historical development of a Buddhist history of ideas, ${ }^{11}$ we are better off to acknowledge plurality and complexity and to grow suspicious of our assumption that liberation must have one face. With this we should forsake the impulse to reduce the practices of the tradition to one strict model. The Nikāyas can be rather seen as a map, or a set of maps, that can take one to different peaks, at each of which we may find a textured liberation, one that has a particular color and feel, and that manifests in the body in its own unique way. With this approach, we may find the corporeal sides of liberation more integral, or at least more relevant to understanding certain types of liberation.

While this study adopts a different approach than many of the studies that discuss the place of the body in Buddhism, which often concentrate on questions of gender and sexuality, it shares their historical and conceptual understanding of complexity as a key feature in the life of the tradition. As discussed in a wide range of illuminating analyses, including Sponberg (1992); Gross (1993); Gyatso (2005); Wilson (2012); Salgado (2013); Collett (2014);12 Cabezón (2017); Langenberg (2017, 2018); and Gummer (2020), the Buddhist tradition, including its textual tradition, harbors a rich array of attitudes and positions in relation to the body, its significance, and its role in Buddhist practice and life. This

\footnotetext{
5 An apt example for the present case comes from Rita Gross's classic Buddhism after Patriarchy (Gross 1993, pp. 159-60): “Egolessness is not a nihilistic condition nor the attainment of non-existence, as opposed to existence. It is not a vacuous state of non-perception and non-thinking ... An egoless person is quite the opposite of a zombie. Rather, she is cheerful, calm, humorous, compassionate, empowered, and energized because she has dropped the burden of ego. She has found a sane, healthy, and mature way of being free within the world" (emphasis in the original). While I find much to commend in Gross's study, including in her historical approach to early Buddhism (chp. 4), this perception of liberation overly simplifies the picture.

6 See notes 1-3 above.

As discussed in the Mahāvedalla-sutta (MN I.296-298).

As at DN II.70-71 and II.111-112.

E.g., MN III.77.20.

10 The paradigmatic formulation here is de La Vallée Poussin (1937); see further Schmithausen (1981); Gombrich (1996, chp. 4). For plurality of liberations, see further Ben-David (2017); Shulman (2017a).

11 Such an a approach characterizes classic studies such as Bronkhorst (1993); Vetter (1988), and most distinctively Schmithausen (1981).

12 I refer mainly to Collet's own introduction and chapter 3, yet most of the other articles in the volume contribute to this discourse.
} 
diversity speaks of multivalence and tolerance at the intersection between ideology and practice, and makes room for personal experimentation and creative self-reflection in the development of Buddhist self-identity. These grounded approaches can be meaningfully distinguished from the main mood of normative texts, which inclines toward an ideology and a vision of practice that is oriented toward masculine dominance and that often takes an ambivalent, if not starkly negative, view of the body. Siding with these studies in seeing the body as an integral part of the life of tradition on the ground, and adopting the theoretical opportunity they afford for appreciating plurality and complexity, this study aims to unearth the positive role attributed to the body in seminal contexts of the Buddhist path to liberation, including with respect to liberation itself.

In what follows I will analyze depictions of the Buddha's body, alongside formulations on advanced stages of meditative practice, in the early discourses of the Pāli Tipitaka, striving to theorize the significance of the body for the early Buddhist tradition. My position will be that there are, or at least that there can be and that there is strong evidence for, distinct somatic aspects to the early Buddhist notion of liberation, which attribute an ideal body to the Buddha that is almost unrelated to his sexual and gendered, male existence. In doing so, my approach will be markedly distinguished from what I take to be the two most significant assessments of the nature of the Buddha's body that have been produced in scholarship on the early tradition, those of Michael Radich and John Powers.

Radich, in his extensive and rich 2007 dissertation on "The Somatics of Liberation," offers a discussion that is evidently relevant to our theme. For him, there has to be a corporeal dimension to liberation, which should not be understood "as a purely gnostic, cognitive, or 'spiritual' matter. Rather, this religious goal must logically entail some somatic dimension," which is required given "the transcendence of all suffering and therefore all species of conditionality and limitation that give rise to suffering." ${ }^{13}$ Nevertheless, for Radich, the relation to the body in early Buddhism is "overwhelmingly negative," while all talk about the body in the early tradition sees it as "a bad thing" (p. 19), so that the somatic ideal of early Buddhism is one of disembodiment. According to Radich, the positive ideal of embodiment matured only in the Mahāyāna, while steps toward this achievement were taken within the early tradition, mainly through the idea of the "mind-made body" (manomaya-kāya) and through the doctrine of the 32 marks of a great man. In relation to Radich's position, my argument is quite simple-there is clear evidence for a positive ideal of the body in early Buddhism, and indeed that-as Radich himself suggested in such a compelling manner-there is a somatic dimension to liberation throughout Buddhism, although this approach probably had to contend with other, conflicting approaches that denied the body. I thus side with Radich's emphasis on "the somatics of liberation," but push the positive view of embodiment that Radich attributes only to the Mahāyāna back to the days of early Buddhism as well.

John Powers, in his influential Bull of a Man: Images of Masculinity, Sex and the Body in Indian Buddhism, offers a rich analysis of the Buddha's body throughout Indian Buddhism, which highlights the bodily aspects of the Buddha's perfection and stresses the importance of "the physical displays of his awakening" (p. 21). While Powers makes it natural to inquire into the embodied dimensions of awakening, his own efforts are directed mainly to depicting the Buddha as "the ultimate man" and as "a paragon of masculinity", whose qualities include "his extraordinarily beautiful body, his superhuman virility and physical strength, his skill in martial arts, and the effect he has on women who see him" (p. 1). While there is much to commend in Powers' study, and he is surely aware that the ideals of bodily perfection that influenced Buddhist India are different than ones that dominate the modern West, this portrayal of the Buddha does not, in my reading, have a real grounding in Sutta

13 Radich (2007, pp. 17-18). In the present context I offer only a short summary of Radich's expansive, complex, and quite fascinating discussion, focusing only on his arguments about early Buddhism ... I also make no claim regarding the argument that is central to his thesis that there is no real evidence for origins of the concept of the dharmakāya in early Buddhism, and suspect that he is correct. 
literature in Pāli. ${ }^{14}$ In this textual corpus, the Buddha is seen as an ideal human being, but it highly questionable if this includes being an "ideal male" (p. 20). Such conceptions fit, perhaps, the Sanskritic sources that Powers relies on most heavily-the Lalitavistara, Buddhacaritam, and the Mahāvastu (which is partially in Sanskrit), and can connect with later Pāli materials from Buddhaghosa and the commentaries. For the Pāli Suttas, however, the Buddha's bodily perfection is subtler and remains almost asexual. As Powers argues, his perfection manifests in his body in evident ways, most distinguishably through the doctrine of the 32 marks of a great man (see below). There is, however, little evidence that it refers to masculinity: all audiences are impressed by his presence, which appears to be evident in the very way the Buddha carries himself, yet this applies at least as much to men, his main audiences, as it does to women; ${ }^{15}$ if he has any special physical strengths, these result from his unique understanding, which penetrates the secrets of nature and thereby controls nature. ${ }^{16}$ While I make no attempt to cater to the Buddhist modernist sentiment that may deny the sexual aspects of the Buddha, the Buddha of the Nikāyas does-as a literary figure-seem to display no interest in sex and his bodily perfection does not relate to his masculinity. ${ }^{17}$

\section{The Buddha's Perfect Body}

One way to approach these issues is to examine the manner in which the authors of the early Suttas related to the body of the Buddha. See the following passage from the Majjhima Nikāya's (MN) Brahmāyu-sutta ("Discourse with Brahmāyu", no. 91). Here, Uttara, the chosen student of the prominent, aged Brahmin Brahmāyu, describes the manner in which the Buddha carries his body:

When he walks, the honorable Gotama steps with his right foot first; he does not raise his foot too far and does not place it too near; he does not walk too fast or too slowly; he walks without knocking his knees against each other or knocking his ankles against each other. When he walks, he does not turn his thighs up or down, or twist them this way or that. When he walks, he instigates movement only with the lower part of his body. He walks without exerting any bodily force. ${ }^{18}$

This is a rare and inspiring description of the Buddha's gait, which attests to the evident bodily aspects of his liberation. Regular people like us may at times begin to walk with our left foot, yet for the Buddha this is both practically and metaphysically impossible, as he will always begin his movement with his right foot. As the commentary says, "this is a perpetual miracle" (satatapattihāriyam etam). While this element seems more metaphysically oriented, what follows is more grounded, and we are told that the Buddha walks in complete equilibrium and precision, raising and placing his feet in a manner that maintains balance and composure, and doing so naturally and effortlessly. He also walks at a convenient pace, which maintains a sense of well-being and ease. Most impressively, "he instigates movement only with the lower part of his body, without exerting any bodily

14 Issues of comparison with other extant versions of the early discourses may reveal interesting insights, but should not be thought to bring us closer to the historical realities of early Buddhism. Each textual tradition offers its own version(s) of discourses, which conform to local tastes and standards. Thus, we could read Chinese versions of Suttas in order to understand ideals of masculinity in early Chinese Buddhism, not in order to return to the days in which the texts were composed, supposedly before the schisms. See further Shulman (Forthcoming, chp. 1).

15 See for example the manner in which the Buddha enters paribbājaka-assemblies is texts such as the Udumbarika-sutta (DN 25), or the Cūlasakuludāyisutta (MN 79), or the manner in which he impresses Saccaka the Jain philosopher (see below) in the Cülasaccaka-sutta (MN 35, at MN I.233.35-36) with golden body.

16 See Shulman (2017b).

17 For an interesting demonstration, see the Migajāla-sutta (SN IV, no. 63), in which the Buddha defines one who "abides alone" (ekavihārī), and compares him to one who abides with another (sadutiya-vihär $\bar{\imath})$, that is who has a wife $($ dutiy $\bar{a})$. The first does not delight in the senses, so that even if his sits near a village surrounded by a many people, he is considered to be alone. The second delights in the senses so that "for him, desire is a wife; and for it, she has not been abandoned" (SN IV.36.29-30: tanh $\bar{a}$ hissa dutiyā, sāssa apahīnā).

18 MN II. 137: gacchanto kho pana so bhavam gotamo dakkhineneva pādena pațamam pakkamati. so nātidūre pādam uddharati, nāccāsanne pādam nikkhipati; so nätisīgham gacchati, nätisaṇikam gacchati; na ca adduvena adduvam sañghaț̣ento gacchati, na ca gopphakena gopphakam sañghațtento gacchati. so gacchanto na satthiṃ unnāmeti, na satthim onāmeti; na satthim sannāmeti, na satthim vināmeti. gaccha[n] to kho pana tassa bhoto gotamassa adharakāyova iñjati, na ca kāyabalena gacchati. 
force," a statement that suggests that he has penetrated some of the secrets of bodily health; he seems to use no unnecessary muscle tension, so that there is no negative influence of his movements on his spine or skeleton, and he maintains perfect balance. This appears as a marked change in his body that is afforded by his liberated consciousness; or, simply, by his liberated body.

See the following description of correct posture, written by Feldenkrais (1985, p. 54), creator of the Feldenkrais method of "awareness through movement":

"the common association of good posture with poise- that is, mental and emotional tranquility - is in fact an excellent criterion of good posture. Neither excessive muscular tension nor emotional intensity is compatible with good posture. Good posture means acting fast without a hurry; hurry means generally heightened activity that results not in faster action, but only in increased muscular contraction. Good posture means using all the power one possesses without enacting any parasitic movements."

Without laboring the comparison too much-the theoretical contexts of early Buddhism and the Feldenkrais method are far from each other-Feldenkrais makes a connection between a calm and healthy mental state and the way one carries one's body. Using one's body in a healthy way implies balanced pace, focused action, and adequate muscle tone. Later on, Feldenkrais discusses the manner in which anxiety affects breathing, how emotion impacts muscle tone, and how tensions express themselves in different types of stiffness and muscle contractions. ${ }^{19}$ His understanding of the body and its relation to mental health helps us see that the authors of the Brahmāyu-sutta are telling us something about the nature of the Buddha's liberation through this description of his body-his calm and tranquil body is an attainment in itself, which also attests to his perfect mental equilibrium.

This description continues with a characterization of other aspects of the Buddha's use of the body, including the way he looks, sits, eats, teaches and wears his robes. I quote parts of this long, remarkable section in order to demonstrate the care in which the Buddha's bodily comportment was described. This description is part of the effort to visualize the Buddha and contemplate his figure in as compelling a way as possible, an act of Buddha-anusmrti. Although it also relates to mental aspects of his being, the focus is on the body, while the details reflect genuine care for what would constitute an awakened bodily being:

When the honorable Gotama looks, ${ }^{20}$ he does so with his whole body; he does not look up or down; he does not walk looking about, and keeps his gaze a plow-length ahead. Beyond that he has unveiled knowledge and vision.

When he enters a house, he does not bend his body up or down, or twist it this way or that; he does not turn too near or too far from his seat; he does not sit while leaning his hands on his seat, and he does not throw his body down on the seat.

Sitting indoors, the recluse does not toy with his hands or feet; he does not sit placing one knee upon the other, nor does he place one ankle on the other. He does not sit leaning his jaw on his hand. When seated indoors, the recluse is not afraid; he does not shake, tremble or worry. He has no fear, no shake or tremble, no worry, because he has lost all anxiety. The honorable Gotama sits indoors composed in seclusion.

When he takes water for his bowl, he does not raise or lower the bowl, nor does he bend or twist it. He does not take too much or too little water for the bowl.

19 See especially Chapters 8 and 12 .

20 Apaloketi. This refers to a special look that the Buddha uses, as he did when he gave Vesāli its last glance in the Mahāparinnibbāna-sutta (DN II.122). The commentary there refers to this as a "Nāga glance", which is a turning of the whole body that is afforded by the Buddha's unique physiognomy, in which the bones (of the spine) seem not to touch each other. 
He does not splash when he rinses the bowl; he does not turn it over and over; he does not place it on the floor to wash his hands, but as he washes his hands he washes the bowl, and as he washes the bowl he washes his hands; he throws out the water neither to far or to near from his seat, and he does not scatter it about." 21

This description continues for some time, paying particular attention to the manner in which the Buddha eats. We learn that there is a perfect correspondence between the Buddha's calm body and his tranquil mind. He acts in complete mindfulness-he does not fidget with any part of his body; even his gaze is absolutely relaxed; he seems to move in utter harmony and precision, with no excessive effort. Most impressive is perhaps the statements regarding the ease with which he carries the weight of his body-he does not lean on his hands while sitting, nor rest his jaw on his hand; when he sits down, he does not drop his body and throw himself on the seat, but seems to gently and mindfully bring down the weight of the body to the seat, never losing control. These descriptions express an advanced bodily awareness. ${ }^{22}$

For the authors of the Brahmāyu, the Buddha's awakening manifests in important ways in his body. His movement is characterized by freedom, softness and grace, so that his philosophy receives somatic expression. While this description of the Buddha's body should not be taken as an official doctrinal position of the tradition, it reflects an intuition that was important to certain Buddhists. We now move to examine the role of the body in advanced meditation, which will allow us to consider the somatics of enlightenment more carefully.

\section{The Body in Advanced Meditation}

The emphasis on the Buddha's bodily perfection we encountered fits the conception of advanced practice in meditation in many of the early Suttas. It is clear that the moral dimension of practice, which characterizes the earlier stages of the Buddhist path, has a strong bodily component in its effort to alter the dynamics of desire and to overcome passion. ${ }^{23}$ The monk ${ }^{24}$ must control his eating, passions, and behavior, so that he is distinguished by the collected way with which he uses his body. According to classic presentations of the path, such as the outline of the gradual practice presented in the Sāmaññaphala-sutta that is repeated in the next 11 discourses in the first section of recitation of the Dīgha Nikāya (DN), the Chapter on Morality (Sîlakkhandhavagga, SKV), this moral training is meant to prepare the Buddhist practitioner for advanced meditation, crowned by the attainment of the four jhannas that lead to awakening. As our analysis in this section will reveal, such advanced meditative states, in which liberation is said to occur or which

21 MN II.137-138: gacchanto kho pana so bhavam gotamo dakkhineneva pādena pațamam pakkamati. so nātidūre pādam uddharati, nāccāsanne pādam nikkhipati; so nātisīgham gacchati, nātisanikam gacchati; na ca adduvena adduvam sañghațtento gacchati, na ca gopphakena gopphakam sañghațtento gacchati. so gacchanto na satthim unnāmeti, na satthim onāmeti; na satthim sannāmeti, na satthim vināmeti. gacchato kho pana tassa bhoto gotamassa adharakāyova iñjati, na ca kāyabalena gacchati. apalokento kho pana so bhavam gotamo sabbakāyeneva apaloketi; so na uddham ulloketi, na adho oloketi; na ca vipekkhamāno gacchati, yugamattañca pekkhati; tato cassa uttari anāvațạ ñānadassanam bhavati. so antaragharam pavisanto na kāyam unnāmeti, na kāyam onāmeti; na kāyam sannāmeti, na kāyaṃ vināmeti. so nātidūre nāccāsanne āsanassa parivattati, na ca pānininā ālambitvā āsane nisīdati, na ca āsanasmị̀ kāyam pakkhipati. so antaraghare nisinno samāno na hatthakukkuccam āpajjati, na pādakukkuccam āpajjati; na adduvena adduvam āropetvā nisīdati; na ca gopphakena gopphakam

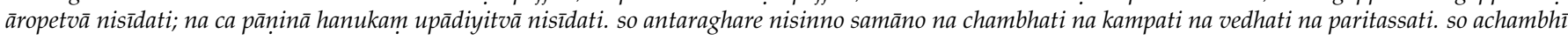
akampī avedhī aparitassī vigatalomahamso. vivekavatto ca so bhavam gotamo antaraghare nisinno hoti.. so pattodakam pațigganhanto na pattam unnāmeti, na pattam onāmeti; na pattạ̣ sannāmeti, na pattam vināmeti. so pattodakam pațiggaṇhāti nātithokam nātibahum. So na khulukhulukārakam pattam dhovati, na samparivattakam pattam dhovati, na pattam bhümiyam nikkhipitvā hat the dhovati; hatthesu dhotesu patto dhoto hoti, patte dhote hatthā dhotā honti. so

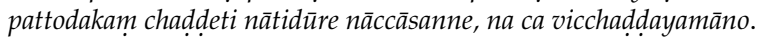

22 Powers (2009) discusses the Brahmāyu shortly, referring mainly to Brahmāyu's conversion experience following his encounter with the Buddha, which relies on the search for the marks of a great man (p. 15). Power does not discuss at length the more subtle passage we read above (see the short reference on p. 16). Notice the mistake he makes in note 87 on page 256, in which he confuses between the figures of the Brahmin teacher Brahmāyu and his student Uttara. The more elusive suggestions in relation to the underlying sexual allusions in the Brahmāyu, raised by Gummer (2020) are more compelling.

23 For an enlightening discussion of the relation between the body and morality in Buddhism, see Mrozik (2007, esp. chp. 4).

24 I speak here generically about a male practitioner, in accord with the emphasis of the literature, even though this is a normative position that probably does not reflect the state of things on the ground, in which there women who were adepts in meditation as well; See Sponberg (1992) and Gross (1993). 
can themselves be seen as a form of liberation, ${ }^{25}$ can have a powerful somatic dimension. This will suggest that the body is not only helpful in generating liberation events, but is a very part of them. Thinking of liberation only in terms of "insight", as a cognitive, perceptual or even emotional transformation, is misleading.

Here, it is important to emphasize that in investigating important statements on the body in advanced meditation, we are not searching for a comprehensive account of the tradition, as if there is just one path to one liberation. Rather, we will be reflecting on a number of representative accounts that reveal intuitions about the body that were active among early Buddhist meditators and theoreticians. Most of the materials I will introduce will be familiar to the specialist, while the textual excerpts are meant to allow a close reading that is sensitive to statements on the body that are too easily overlooked.

Our main textual example comes from the Kāya-gatā-sati-sutta (KGSS), "The Discourse on Mindfulness Directed to the Body" (MN 119). This text is intimately related to a group of discourses that present early Buddhist practices of mindfulness (sati), including the seminal Sati-patțanna-sutta (The Discourse on the establishing of Mindfulness, MN 10) and its DN parallel and elaboration in the Mahā-sati-patthāna-sutta ("The Great Discourse on the Establishing of Mindfulness", DN 22), ${ }^{26}$ as well as the well-known Ānāpāna-sati-sutta ("Mindfulness of Breathing", MN 118) and the "Collection on Mindfulness" in the Satipatthanna-samyutta. ${ }^{27}$ Each one of these texts has its own emphases, which intersect with maps of advanced practice and liberation that are found in other texts, ${ }^{28}$ but we naturally focus on a discourse in which the discussion of the body is prominent.

After a formulized opening that marks the text as one of particular importance, ${ }^{29}$ the Buddha proceeds to instruct the monks about "mindfulness directed toward the body", asking how it can "be developed, made familiar, of great fruit and benefit"? ${ }^{30}$ He will then answer by describing how "a monk who has gone to the forest or to the root of a tree sits having crossed his legs, placed his body erect, and positioned his mindfulness in front of him. ${ }^{\prime 31}$ With this we already sense the concrete, embodied dimension of the instruction, which is shared by the different discourses in the mindfulness cycle. ${ }^{32}$ The Buddha now repeats the well-known list of six practices that relate to mindfulness directed at the body from the Sati-patthanna-sutta, including mindfulness of breathing, the mindfulness of bodily positions and actions, the observation of bodily organs, the analysis of the body according to the four elements, and the set of charnel ground meditations. All these are deeply embodied practices that rely on the observation of the body in the effort of perceiving its impermanent nature and creating a sincere attitude of dispassion. While the focus in these

25 Vetter (1988) and Bronkhorst (2009) are among the scholars who see liberation as the attainment of such a meditative state, so that descriptions of liberation as including a cognitive or philosophical dimension were later developments. Arbel's (2017) more recent study also takes a related approach.

26 See analysis of these texts in Kuan (2008); Shulman (2014, chp. 3).

27 This is the third chapter of the fifth book of the SN, "The Great Book" (Mahä-vagga). Supposedly, this collection and others of its sort collect relatively short statements on mindfulness, which purport to have been uttered by the Buddha. More realistically, these are legitimate elaborations on the theme of mindfulness according relevant formulas. I intend to discuss this theme in future publications.

28 A prominent example would be the practice of $j h \bar{a} n a$, or the analysis according to the perspectives of non-self in relation to the aggregates, both prevalent themes in the literature; the first forms a central part of the KGSS, while analysis of the aggregates is alluded to in the Sati-patthāna-sutta (but not in its Chinese parallels).

29 Nikāya discourses have their subtle literary strategies to mark texts and themes as valuable; here, the Buddha interrupts a group of monks in their discussion after knowing of it through his supernatural hearing powers, as happens in such seminal texts as the Ariyapariyesana-sutta (MN 26) or the Mahāpadāna-sutta (DN 14). See also the, Mahāyāna-like opening of the Ānāpāna-sati-sutta (MN 118), placed immediately before the KGSS and impacting its reading, in which the Buddha teaches a large, magnificent assembly on the night of the full moon. More generally, the last section of recitation in the $\mathrm{MN}$, which includes its final 52 discourses, contains many discourses that can be seen as relatively late and mature formulations on meditation; see also MN 121 and 122.

30 MN III.89.8: kathaṃ bhāvitā can bhikkhave kāyagatā sati kathaṃ bahulīkatā mahapphalā hoti mahānisaṃsāe

31 MN III.89.10-12.

32 In assessing the early Buddhist textual tradition, I follow the approach developed in Shulman (Forthcoming), which is sensitive to the literary, and more broadly to the creative, nature of the early discourses, so that these texts are no longer understood mainly as attempts to preserve the Buddha's teachings. Authors and editors were continually composing and reshaping texts, as a legitimate practice within Buddha-vacana. In this sense I speak of a "mindfulness cycle" of texts, that is an array of texts that develop resonant themes, but which need not necessarily reduce to a systematic theoretical structure that has backing in the historical teachings of one individual. 
meditations in not on conducting action with the body, they call for an intense observation of the body as a rich point of reference. Here we will not rehearse the details of these practices, which have received much attention already, ${ }^{33}$ but concentrate on the context in which they are framed. The powerful impact of the observation of the body is evident in the short, pregnant refrain that concludes each meditation:

For him who abides diligent, ardent and resolute, the thoughts and memories that are based on the household life fade away. After their fading away, his mind settles inwardly, calms down, unifies and concentrates. In this way too, monks, a monk develops mindfulness directed to the body. ${ }^{34}$

For the monk who practices mindfulness of the body and who carefully analyzes his bodily experience, the memories and thoughts that are based on the homelife (gehasit $\bar{a}$ sarasamkappa $)$, that is the patterns of desire in thought and emotion that were developed through one's earlier experience while living a (more or less) normal life in society, diminish. This dense formulation reveals a deeply transformative process, which occurs in a subjective space that spans both physical and mental aspects. ${ }^{35}$ This is also an important development that prepares the monk for advanced meditation, which reflects a deep internalization of the Buddhist moral stance that is a prerequisite for reaching meditative attainments. Indeed, the text now proceeds to describe the attainment of the four jhānas, including them within mindfulness directed to the body. ${ }^{36}$ Here, the familiar depiction of the first jhāna- "and then, monks, having detached from unwholesome states, a monk attains and abides in the first jhāna, which has thought and analysis, which is born of seclusion and is characterized by joy and bliss" 37 - is followed by the following statement that highlights the somatic nature of the attainment:

He drenches, suffuses, fills, and pervades this very body (imam eva kāyam) with joy and bliss born of seclusion, so that there is nothing in his whole body (sabbāvato kāyassa) that is untouched (apphutam) by joy and bliss born of seclusion. ${ }^{38}$

This jhannic experience is here an evidently corporeal one, whose defining feature is a sense of pleasure that thoroughly suffuses the body. ${ }^{39}$ This condensed description is followed by a powerful simile, which bolsters the sense of a profound bodily experience:

Monks, just as a skilled washer or a washer's apprentice would spread soappowder on a bronze dish, and sprinkling it more and more with water, mixes it so that [he shapes] a ball of soap filled with moisture (sneha ${ }^{40}$, suffused with moisture, pervaded by moisture inside and outside, without trickling, so [he drenches ... the body ... . . ${ }^{41}$

This simile offers a cogent image for the intense bodily experience in the first jhanna, likening it to a ball of soap that is thoroughly pervaded by moisture and grease. The text then concludes the portrayal of this meditative state with the same passage with which it describes all practices concerned with mindfulness directed to the body regarding the

33 See Collins (1997, pp. 192-94); Anālayo (2003); Shulman (2010, 2014, chp. 3.1).

34 MN III.89.20-24: tassa evam appamattassa àtāpino pahitatassa viharato ye te gehasitā sarasaṃkappā te pahīyanti, tesam pahānā ajjhatam eva cittam santiț̣hati sannisīdati ekodihoti samādhiyati. evam pi bhikkhave bhikkhu kāyagatạ̣ satim bhāveti.

35 For sake of clarity, I do not necessarily assume that the events described in the texts took place in the hearts and minds of real meditators; yet I do believe that they reflect practice to some degree, and at least express an idealised vision of it.

36 On the question of the relation between sati and jhäna see Kuan (2008, chp. 3), Shulman (2010, 2014, chp. 3.2).

37 MN III.92.23-25: puna ca param bhikkhave bhikkhu vivicc' eva kāmehi vivicca akusalehi dhammehi savitakkam savicāram vivekajam pītisukham paṭhamajhānam upasampajja viharati.

38 MN III.92.25-28: so imam eva kāyam vivekajena pītisukhena abhisandeti parisandeti paripūreti parippharati nāssa kiñci sabbāvato kāyassa vivekajena pütisukhena apphutam hoti.

39 See further the corresponding emphases on this passage in Langenberg (2018, p. 7).

40 Sneha implies here both moisture and grease.

41 MN III.92.28-32: seyyathāpi, bhikkhave, dakkho napāpako vā nahāpakantevasī vā kañtathāle nahāniyacunnāni ākiritvā udakena paripphosakam paripphosakam sanneyya, sā' 'ssa nahāniyapiṇ $\bar{\imath}$ snehānugatā snehapperatā santarabāhirā phutā snehena, na ca paggharini, evam eva ... . 
fading of memories and thoughts that are related to the homelife. ${ }^{42}$ Indeed, it seems that this fading away intensifies with each meditation.

The descriptions of the next three jhannas follow the same pattern. For them too, the experience is described as a profound bodily event in which the whole body is pervaded by a sense of "joy and bliss that is born of concentration" (samädhijena pitisukhena) in the second jhāna, and a "joy that is devoid of bliss" (nippitikena sukhena) in the third jhāna. The simile that follows then deepens the sense of completeness, depicting the second jhanna as a spring that is filled with cool water that arise from within it, and the third jhanna to lotuses that are fully subsumed within water; again, the care with which these images are presented seems to reflect a powerful bodily experience. ${ }^{43}$ The description of the fourth jhanna is particularly interesting, where the common presentation of the jhāna itself is followed by the statement that- "He sits pervading this very body with a purified, cleansed mind, so that there is nothing in his whole body that is untouched by his purified, cleansed mind." 44 The image that follows is of a man who is completely covered by a white cloth, followed again by the refrain regarding the fading away of the cognitive patterns of the household life. This last statement demonstrates the intimate relation between body and mind ${ }^{45}$ in this deep meditative state-this is not just a purified consciousness, but a thoroughly cleansed consciousness in a body, which itself is thoroughly perceived and experienced by the practitioner. We will return to this issue regarding the relation between body and mind below.

It is important to emphasize that the bodily emphasis in the experience of $j h \bar{a} n a$, the paradigmatic states of advanced meditation in early Buddhism, ${ }^{46}$ is not an idiosyncratic contribution of the KGSS. Rather, it appears in numerous texts, and most significantly in the long formula on the gradual path that forms the doctrinal core of the discourses of the SKV. ${ }^{47}$ This is therefore a seminal doctrinal formulation, which is reproduced in the KGSS since it fits its emphasis on the body. All these texts interpret $j h \bar{a} n a$ as powerfully connected to the body.

Rupert Gethin ([1992] 2001, chp. 5, esp. pp. 170-71) has emphasized the complementary of the scheme of the path to liberation in the SKV with the description of the 7 bojjhangas, the "limbs of enlightenment." ${ }^{48}$ This doctrine offers a corresponding depiction, or theorization, of jhannic experience, employing a list of seven stages or events that progress along the meditative path, beginning with sati ("mindfulness"), proceeding though "analysis of dhammas" (dhamma-vicaya), "energy" (vìriya), bliss (piti), and tranquility (passaddhi), and culminating with samādhi ("concentration") and "equanimity" (upekkhā). While it is questionable whether this doctrine should be interpreted as completely equal to the elaborate depiction of the gradual path in the SKV—specifically, there is no clear counterparts in the SKV version to the second limb of dhamma-vicaya, the third limb of viriya, and the fifth limb of passaddhi-or whether this is a competing theory of the entrance to jhāna, there

It is interesting to note in this respect the focus made by Cabezón (2017, pp. 223-26) on the jhānas being beyond sexual desire.

43 On paying attention to similes, see Marino (2015).

$44 \quad$ MN III.92.12-15: so imam eva kāyam parisuddhena cetasā pariyodātena pharitvā nisinno hoti, nāssa kiñci sabbāvato kāyassa parisuddhenacetasā pariyodatena apphutam hoti.

45 Here is a place where issues of terminology and translation become particularly vexing. It is far from certain that there is a good correspondence between the modern mind and the Pāli manas, or between consciousness and citta, while the Indic traditions have a much broader set of concepts to describe these terms, including most prominently (in Pāli) viññana, together with a set of terms form attention and awareness, such as sati and

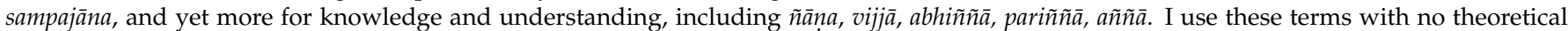
precision here, and look forward to a study that will offer a sober consideration of their meanings, which seem to shift between contexts. Notice that mind, manas, is commonly counted as one of the six senses.

46 See classically in Bronkhorst (1993).

47 See above, p. 8. See further Shulman (2017c). This formula is reproduced in a slightly shortened version in a number of MN discourses, which perhaps due to the effort to shorten the text, do not include the similes and the reference to the body. These parts of the formulas do appear in two more MN texts aside from the KGSS, the Mahāssapüra-sutta (MN 39) and the Mahäsakuludāyi-sutta (MN 77), as well as in the Añguttaranikāya's Pañcangika-sutta (V.28). Notice that classical presentations of the Buddha's awakening in the MN as the Bhayabherava-sutta (MN 4) and the Mahasaccaka-sutta (MN 36, discussed in the next section), do not include the reference to the body and keep the shorter version. This could be seen as a different interpretation of $j h \bar{n} n a$, but could also relate to textual considerations such as length of texts and issues of orality.

48 See also Arbel (2017, chp. 4). 
is a remarkable correspondence between the approach of the KGSS and the theory of the seven limbs. In the latter, the creation of a rich samädhi experience that generates a sense of equanimity (upekkhā), the sixth and seventh limbs, follows a contemplative process that begins with sati, the first limb, and moves through experiences of bliss (piti), the fourth limb, and of joy (sukha); all these terms are central to the common conceptualizations of jhāna. Interestingly, in the scheme of the seven limbs of enlightenment, joy is achieved through the practice of tranquility (passaddhi), which is explicitly said to include both a mental and a bodily aspect, while joy itself allows the mind to concentrate in samādhi. ${ }^{49}$ Thus, in this independent conceptualization of jhänic experience, we discover again an important emphasis on bodily experience. Notice that in the classic, parallel account in the MN, the idea that "the body is tranquil, calm" (passaddho kāyo asāraddho) is expressed as part of the description that marks the readiness of the practitioner to enter jhana. ${ }^{50}$

Beyond this emphasis on the body in the theorization of the four jhänas and of jhänic experience more broadly, we should also note that at least some authors or practitioners saw the body as related to the attainment of the following four "formless attainments." In a recurrent formula we find a meditator who "abides having touched those quiet deliverances that are formless, having surpassed form, with his body." ${ }^{\prime 51}$ Perhaps this passage should be understood along the lines of de La Vallée Poussin's (1937) famous analysis, who sees them as "mystical", so that practitioners may "touch nirvāna with their body," distinguishing between them and more "intellectual" approaches. In the context of our discussion, these accomplishments clearly seem to be embodied, tangible, and concrete. ${ }^{52}$

We have seen so far that for the KGSS, together with other important textual sources, states of advanced meditation are presented as containing a powerful somatic dimension. Yet although these states are clearly connected to normative visions of liberation, liberation itself is often thought to require the more cognitive focus of insight or wisdom (vipassanā, pañ $\tilde{n} \bar{a}, \tilde{n} \bar{a} n a, v i j j \bar{a}$, etc.). The continuation of the discourse works in this direction by highlighting the positive impact that developing mindfulness of the body can have on establishing wisdom and understanding within one's consciousness. The text follows the description of the four jhannas with a statement on how "anyone for whom mindfulness directed to the body is developed and expanded, for him (will appear) any inward (an-

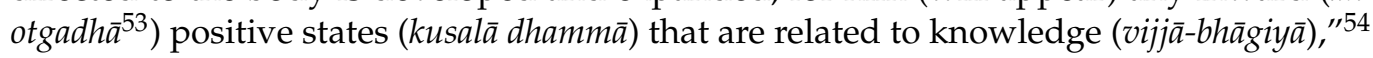
likening this situation to rivers that are subsumed within the ocean. The discourse now brings in a number of similes to state that Māra will find no opportunity to confront whomever has developed mindfulness directed to the body. It then expresses the mental freedom and control that such a practitioner would enjoy, by explaining how he can "direct the mind to any state that is to be realized by direct understanding, and achieves there the full capacity for witnessing." ${ }^{\prime 55}$ Continuing its penchant for rich similes, the text suggests

49 See for instance in the Käya-sutta, the second discourse of the Bojjhanga-samyutta (SN V.64), which states."And what, monks, is the nutriment for the arising of the un-arisen tranquility limb of enlightenment, or for the development and fulfillment of the tranquility limb of enlightenment? There is, monks, tranquility of body and the tranquility of mind ... " (SN V.66.22-24: ko ca, bhikkhave, ähäro anuppannassa vā passaddhisamboijhangassa uppādāya, uppannassa vā passaddhisambojjhangassa bhāvanāya pāripūriyā? atthi, bhikkhave, kāyapassaddhi, cittapassaddhi); for the discussion of the significance of the notion of "nutriment (ahära) in the scheme of the bojjhangas, see Gethin ([1992] 2001, pp. 175-77). The following Sïla-sutta says a little bit more. "The body of one who is filled with bliss (pïti) tranquilizes, and his mind tranquilizes as well" (SN V.27-28: pittimanassa kāyopi passambhati, cittampi passambhati). After explaining that this relates to the arising of the limb of enlightenment of tranquility, the text concludes that "for the joyful one whose body is tranquil, the mind enters concentration" (SN V.69.1-2: passaddhakāyassa sukhino cittam samādhiyati). Notice that the PTS edition opts here for a variant reading — passaddhakāyassa sukham hoti. sukhino cittam samädhiyati—that suggests that there were different understandings of this process within the tradition.

50 E.g., MN I.21.33.

51 E.g., MN I.33.34-35, or 479.5-6: ye te santā vimokkhā atikamma rūpe āruppā ten a kāyena phasitvā viharati.

52 See also the interesting passage from the Indriya-samyutta of the SN (V.230.18-19), which defines the practitioner who has gone beyond training (asekha) as one who in relation to the full capacity of the five faculties (indriya) "abides having touched them with the body and see having penetrated them with wisdom (kāyena ca phusitvā viharati pañ̃naya ca ativijjha passati).

53 The best reading for this term is the parallel one, induced also by the commentaries, of antogatā.

54 MN III.92.22-23: yassa kassaci bhikkhave kāyagatā sati bhāvitā bahulīkatā antogadhā tassa kusalā dhamma ye keci vijjābhāgiyā.

55 The full quote of this enigmatic passage reads-MN III.96.16-19: yassa kassaci bhikkhave kāyagatā sati bhāvitā bahulīkatā so yassa yassa abhiñ̃ñasacchakarayassa dhammasa cittam abhininnāmeti abhiñ̃̄āsacchikiriyāya tatra tatra eva sakkhibavyatam pāpuñāti sati sati-äyatane. 
that this freedom is equal to the ability of a strong man to spill water from a pitcher that is full to the brim by tilting it in any direction, or to the power of a capable driver to direct an excellent carriage led by quality horses on flat land, and to turn it in different directions. The discourse concludes by listing the ten benefits that a monk who has well-developed mindfulness of the body may be expected to reap, beginning with overcoming different sorts of discomfort and fear, moving through an ability to easily cruise the jhānas as he wills and to develop supernatural powers, and reaching the achievement of the defining liberating understandings regarding the knowledge of former births, of other peoples' karma, and of the destruction of the inflows. Again, it seems clear that for the authors of the KGSS, liberation is not from bodily experience, but relates rather to a certain way of being in the body.

\section{Body and Mind}

My argument so far has been that at least for important strands of the early Buddhists textual tradition, liberation was thought to take place in the body, and that such a profound experience had a clear somatic dimension. Given the variegated quality of liberationperhaps we should simply move to speaking of liberations in the plural-we do not need to identify a universal principle at work here regarding the bodily dimensions of awakening: how should we, for example, understand the ubiquitous formula that marks liberation, in which a monk knows (päjanāti), or has realized (abhañ $\tilde{a} \bar{s} i)$ "birth is exhausted; the holy life has been lived; what needs to be done has been done; there is no further being in this state here" ${ }^{\prime 56}$, or the complementary formula- "my liberation is unshaken; this is my last birth; there is no more return here" ? ${ }^{57}$ These are carefully phrased statements regarding the quitting of rebirth, anotion that denies any element in reality, not just the body, so that the transcendence it speaks of is not only of the material. Or, how should we relate to passages that speak of liberation as a distinct meditative state ${ }^{58}$ Here the bodily aspect of the experience seems integral, even if it is not the focus of the event, which may be noetic. It is not only that the idea of liberation is polyvalent, but that the discussion of the body itself moves between opposite poles of disgust and glorification, the latter referring mainly to the body of the Buddha or of certain monks. ${ }^{59}$ Rather than trying to reach a final verdict on the role of the body in liberation, it is enough for us to observe that at least in some cases, the experiences of advanced practice-as close to "liberation" as we will attempt-can include an evidently somatic component. Here we spoke mainly of texts from the mindfulness cycle, as well as seminal conceptualizations of jhāna.

One important question that comes up through this reflection concerns the relation between body and mind. In the description of the fourth jhāna in the KGSS, it was suggested that the practitioner's whole body becomes thoroughly pervaded by a comprehensively clarified mind or consciousness. This statement lends itself at the very same time to a dualistic interpretation that would emphasize the clear distinction between body and mind as two discrete entities, or to a lighter interpretation of the difference that would see them as aspects of each other. ${ }^{60}$ Did the early Buddhists take body and mind to be two fully distinct phenomenological or ontological entities, or were they perhaps more closely aligned? Could it be true that for this tradition, an achievement of the mind would naturally have a bodily correlate? Given that early Buddhist philosophy is taken to be mainly a philosophy of experience, ${ }^{61}$ we may consider approaching this question from a phenomenological perspective of the type articulated by Merleau-Ponty (1962), and to suggest that the body offers grounding for an experience from which the perspectives of the

\footnotetext{
khīnā jāti vusitam brahmacariyam katạ̣ karanīyam nāparam itthatayā'ti.

akuppā me vimutti, ayạ̣ antimā jāti, natthi dāni punabbhāvoti.

See above, p. 2.

Mrozik (2007, p. 84): "The presence of seemingly contradictory body discourses in a single text is not uncommon in Buddhist literature."

60 Another important related formulation is the interdependence between consciousness and "name and form" (nāma-rūpa) articulated by the Mahānidāna-sutta at DN II.62-63.

61 Hamilton (2003); Shulman (2014, chp. 2.1).
} 
bodily and the mental, the inner and the outer, the self and the other, all emerge. Or, more strongly perhaps, we could evoke the basic phenomenological stance that is associated with Husserl, which suggests that phenomenology is an experiential given, and that it should be analyzed on its own terms while bracketing the metaphysical question regarding the ontological nature of the mental and the material; the body, phenomenologically speaking, cannot be divorced from its conscious apprehension. ${ }^{62}$ Furthermore, we could adduce contemporary enactivist approaches that often draw on Buddhist thought, and which understand the mind to emerge out of biological and neural autopoietic complexes, in which a body becomes a "self-specifying" and self-regulating system; thus, the mental and the physical form a continuum. ${ }^{63}$ While further analysis is necessary in order to decipher the relation between body and mind in early Buddhism, and while we could probably identify a polyvalence in this context as with respect to other questions we are entertaining, these approaches help us think of the body not as a mere physical entity that is external to consciousness, but as an integral part of conscious phenomenology.

We can thereby adopt a methodological, naïve-dualist approach with respect to the body-mind relation in early Buddhism, which takes both categories as important for early Buddhist phenomenology and practice, without committing to a particular ontological interpretation. With this we may perceive that for important strands of early Buddhism, the path to liberation was understood as a development of both body and mind, and that the two are closely connected, if not thoroughly intertwined. One interesting context that this theme comes up in is in the polemics between the Buddhists and the Jains. Of special concern is the debate with the Jain-oriented logician Saccaka, who accuses the Buddha in The Great Discourse to Saccaka (MN 36) that Buddhists are only concerned with development of mind, while they avoid development of the body. The Buddha's response underscores his self-understanding as one who is fully developed in both body and mind, while the two rely on each other. He claims that Saccaka, who attempts to define development of body as proceeding from ascetic practice, does not understand true development of body, while regarding development of mind he does not even attempt an explanation. The Buddha teaches that the two are necessary for each other-for an uninstructed disciple, pleasant feelings that arise generate passion, yet once they pass painful feelings occur, which cause one to suffer; for one whose body is undeveloped, the pleasant feelings that arise take control of the mind, while for one whose mind is undeveloped, it will be the painful feelings that overpower his consciousness. This compelling definition contains a counterintuitive side, which Anālayo attributes to a transmission error, ${ }^{64}$ since it seems to confuse between what we would expect to define as the development of the body, i.e., ascetic practices and dealing with physical pain, and what we would assume that development of mind consists of, meaning meditative practice that includes a dimensionof pleasure. ${ }^{65}$ In any case, the Buddha now defines the Buddhist monk as one who is developed in both body and mind, so that he has no passion for pleasures that arise, which is equal to his development of body, while he is not aggravated by the painful feelings as well, which amounts to his development of mind. ${ }^{66}$ In both cases, the pleasant and painful feelings "do not take hold of his consciousness and remain" (vedanā cittam na pariyādāya tiț̣thati). His practice is thus "two-sided" or "double-winged" (ubhatopakkha).

Saccaka is impressed by this statement and asks the Buddha if he is never overpowered by pleasant or painful sensations, and whether this was always so. This question

62 See Gallagher and Zahavi (2008, chp. 2).

63 See Thompson (2017, esp. chp. 10), as well as Gallagher (2005). Thompson's approach draws much from the neurophenomenological approach developed by Varela (1996).

64 Anālayo (2011, pp. 233-34).

65 This counterintuitive element is also apparent in Saccaka's initial formulation, which has the practitioner who is undeveloped in body and mind only to have trouble dealing with painful feelings. Yet for him, suffering that results from bodily (sārîrika) pain results from a lack of development of mind, while suffering from mental (cetasika) anguish ensues from lack of bodily development. In Saccaka's formulation, the problems are caused by the undeveloped side following the other and falling under its power. Thus, for example, "the body follows upon the mind and falls under its power (cittanvayo kāyo hoti cittassa vasena vattati), which results from the body being undeveloped (abhāvitattā kāyassa).

66 See MN.I.239-240. 
spurs a long autobiographical report by the Buddha concerning the path he followed to enlightenment, which synthesizes the two earlier narratives of the Buddha's enlightenment in the MN from the Bhayabherava-sutta (MN 4) and the Ariyapariyesanā-sutta (MN 26). This new description includes a particularly well-known presentation of the ascetic practices that the Buddha-to-be undertook, which is the most important source in Pāli on this classic section of his traditional biography. ${ }^{67}$ This episode narrates how he went through radically extreme ascetic pain, while practicing not only food-prevention, but even breath-prevention, to a degree that he felt the severest pain a human could experience, which nearly brought about his death. This description would fit the idea that he first perfected the development of the body. Yet he then realized that bodily pain would not take him to realization, and turned to the path of jhanna after recalling an earlier experience, understanding that "this is the path to enlightenment" (eseva maggo bodhāya). ${ }^{68}$ Although our intuition tells us that developing the body is equal to dealing with physical pain, an approach that was adopted also by Buddhist storytellers in the past, ${ }^{69}$ the discourse is consistent in ending each description of the Buddha's asceticism with a statement that corresponds to its earlier definition of development of the mind so that "for me ... such arisen painful feelings did not take hold of my mind and remain" (evarüpāpi kho me, Agivessana, $\overline{u p p a n n} \bar{a}$ dukkhā vedanā cittam na pariyādāya tițthati). When the text moves to describe the Buddha-to-be's attainments in meditation, it remains consistent, defining each experience of advanced attainment according to its earlier definition of development of the body— me ... such arisen joyful feelings did not take hold of my mind and remain" (evarūpäpi kho

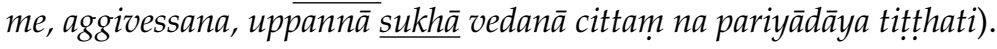

Whatever the solution to the question of textual transmission here is, ${ }^{70}$ the Pāli authors present a compelling approach to the relation between development of body and mind, which clearly sees the two as aspects of each other. According to their statement, advanced realization in meditation and understanding relates to "development of the body." Whether or not there ever was a consistent and fixed definition for development of body and of mind, the emphasis of the Greater Discourse to Saccaka is that the two go together, and that both were necessary for the Buddha to reach enlightenment. ${ }^{71}$

\section{Metaphysics of Embodiment-What Is a Body?}

The discussion we conducted has not resolved the tension in the understanding of the relation between the body and the mind in early Buddhism. Nor did it explain the precise intention of The KGSS in stating that in the fourth jhanna the whole body is pervaded by a thoroughly cleansed consciousness. While further textual analyses may facilitate a more confident definition of the concepts of body and mind in early Buddhism, I wish to conclude the discussion by taking a broader look at the idea of the body in this tradition, while questioning the very nature of corporeality. That is, we must integrate

67 Powers (2009, p. 43) mentions also the radical presentation of asceticism in Mahāsīhanāda-sutta (MN 12); this wild presentation is a good example of the confusion that arises when literary dimensions of texts remain unrecognized. The extreme practices it describes include having the Buddha walking on four and eating cow-dung or urinated upon while lying in a cemetery. None of this relates to any particular power or perfection, but is a literary elaboration on ascetic trials.

68 On the relation to other texts in the MN and the remarkable literary technique of the authors of the Sutta, best perceived at this point, see Shulman (Forthcoming, chp. 6).

69 See the discussion of this text in relation to parallel versions, mainly in different Sanskritic works, in Anālayo (2011, pp. 232-46). These texts should, however, be treated as different versions of the story, so that the attempt for the one true original text pursued by scholars like Anālayo seems misguided. The attempt here is not merely at faithful transmission.

70 Perhaps the simplest solution to the perplexity is that the authors of the Mahasaccaka misplaced the correct titles for the definition of development body and mind in the Buddha's first formulation. Yet the text does seem to rely on a different understanding that he holds throughout, even if it is less convincing.

71 The emphasis on the parallel development of both body and mind fits with the similes the Buddha gives when he begins his final stage of practice. While Bodhi and Ñannamoli $(1995,1229$ n387) and Anālayo (2011, pp. 235-36) feel the simile is misplaced since they understand its message to be that austerities are unnecessary, this reading is an attempt to force the conventionalized themes of the Buddha's life story on the Mahāsaccaka, which has a different focus of polemics with Jainism, thus aiming to show that the Buddha is master of both body and mind. The simile is of the ability to light a fire with wood that must be both dry and sapless, just as a practitioner must be secluded in both bodily and mental respects. See MN I.240-42, reading with VRI and Anālayo (2011,235n152) kāyena ceva cittena ca. 
into our investigation a diversity of perspectives that treat the body within a metaphysical framework that does not locate it in a simply physical dimension.

Although not directly within our line of inquiry, it would be valuable to recall at this point one of the more puzzling contexts that relate to the body of the Buddha-the worship of relics. A distinctive practice of all traditional forms of Buddhist religion in Asia is the high reverence with which the corporeal remains of the Buddha, and more broadly of Buddhist saints, are treated, where they often serve as primary objects of devotion and as highly prized pilgrimage destinations. ${ }^{72}$ Relics remind us that for Buddhist religion, a realized body is not a regular body, and that in some way or another, the physical is not only a remnant of the spiritual, but a direct revelation of it.

In fact, relics may offer us insight into the world of thought that-as in the KGSStakes the realized body to be fully penetrated by the purified mind. ${ }^{73}$ In his fascinating interpretation of the cult of relics, Gregory Schopen speaks of the conception of the relic as "the conception that takes the relic as a living presence animated and characterized by the same qualities that animated and characterized the living Buddha." ${ }^{74} \mathrm{He}$ further shows how for the redactors who wrote some of the inscriptions he studies, the relics are said to be "saturated/invigorated/enlivened by morality, concentration, and wisdom" (p. 154). For him, this implies that "at the very least, this must mean that the relics are characterized by-full of-exactly the same spiritual forces and faculties that characterize, and, in fact, constitute and animate the living Buddha" (p. 154).

These statements cut across the habitual divide between the mental and the physical. Schopen's sources are probably later than the ones we are focusing on here. Yet in interpreting the concept of the body and its role in the soteriological practices of early Buddhism, they offer us an important direction of analysis, which suggests that for at least significant parts of the Indian Buddhist tradition, the body is not simply "a body" in the stark material sense, nor is the awakened mind devoid of physical manifestation. Rather, the two seem to permeate each other, so that the awakened body acts as a corporeal expression of liberated consciousness, and that this even continues after such a person dies. This is, perhaps, one way to deal with the incomprehensible death of such unique, enlightened beings. ${ }^{75}$

Another significant doctrine in this context, which is given much emphasis in Radich's (2007, esp. chp. 2.3) analysis, is the "mind-made body" (manomaya-kāya) that the advanced Buddhist practitioner is said to attain in texts such as the Sāmaññaphala-sutta (see above, p. 8). While such an attainment combats our modern epistemology that valorizes the physical, it fits the overall pattern we are beginning to decipher in which an apparently material body is the product of a mental attainment in advanced meditation. ${ }^{76}$ Even if the presentation of magical powers is considered to be mere ideology or a packaging of the image of the advanced practitioner that is designed to attract new Buddhist converts, ${ }^{77}$ the conceptual map that makes it convincing is quite straightforward-a body can be created through a mind, so that the advanced practitioner who has reached the fourth jhanna and proceeded to develop supernatural power, "turns and directs his mind to the creation of

72 For a valuable historical survey of an array of practices that relate to relics in Buddhism, see Skilling (2005); for remarkable examples of relic veneration in Buddhist traditions, see Seneviratne (1978), as well as Kieschnick (2005, chp. 1).

73 I emphasize that in this statement, or in ones that follow in this section, I do not intend there to be an essential dichotomy between body and mind; rather, I take these categories as phenomenologically and pre-theoretically clear enough to the tradition, while the overall patter is that mental attainment has an important physical manifestation, or that the two are interdependent.

74 Schopen (1997, p. 156).

75 This idea fits well with Strong's (2004) interpretation of relics as an extension of the Buddha's biography. See also the ambiguous attempt by the authors of the Mahāparinibbāna-sutta, who wanted, at the very same time, to retain their Buddha as alive forever and as an impermanent being who dies like the rest of men; see further in Shulman (Forthcoming, chp. 3).

76 We may question whether rüpim must necessarily mean 'material', as it could also mean more generally 'possessing form'; nevertheless, the overall description seems to take this as a regular body, as is confirmed by the commentary's lack of elaboration and acceptance that this body possesses all limbs and faculties.

77 As Maneé (1990) argues in relation to the DN; and compare Grinshpon's (2002, esp. chp. 3) attention to magical powers in the Yoga tradition. 
a mind-made body; and from that body he creates another body, material, mind-made, possessing all major and minor limbs, and whose faculties are not defected."78

The most important expression of the body as a manifestation of spiritual, ethical, and cognizant power is the doctrine that has influenced the understanding of the Buddha's body more than any other, the notion that it possesses the 32 marks of a great man. ${ }^{79}$ This doctrine, which many still try to define as a late development that relates to the later layers of the nikāya discourses, ${ }^{80}$ takes the Buddha's body to possess a set of remarkable bodily marks, which attest to his unique ontological status. He thus has, for example, wheels on the soles of his hands and feet, a golden body to which dust does not stick, a special perturbance on his cranium, 40 perfectly even teeth, a beautiful voice, the torso of a lion and thighs like those of an antelope.

The 32 marks place the Buddha's body between the physical and the metaphysical, ${ }^{81}$ trying to have it both ways. The classic explanation of this practice from the Lakkhana-sutta of the DN suggests that the marks are a physical expression of good deeds performed in the past, so that the Buddha's body appears as a dense manifestation of karma. With this, this discourse offers a concrete, even naturalistic explanation for the process of embodiment, according to which the body is a receptacle of moral and spiritual striving. According to Buddhist understanding, expressed wonderfully in the Jätaka stories of the Buddha's previous rebirths, the Buddha had developed both his body and mind over many, even endless, lifetimes. We thus see how this concrete, naturalistic explanation easily slips into a robust metaphysical position, relying on the doctrine of karma and its cosmological idea of infinite rebirth, as well on as the Buddha's ultimate knowledge of his previous rebirths, through which he reveals his past. As Mrozik (2007, p. 66) says, "for our purposes, the most important point is that the Buddha's body, no less than his heartmind, is the karmic effect of countless lifetimes of virtuous deeds." Mrozik (2007, p. 117) has further offered the compelling theorization not only that "South Asian Buddhists took bodies very seriously", but also "that one of the reasons they did so was because they believed that bodies played critical roles in the ethical development of living beings." Here, we may suggest that this understanding be advanced one step further to see the body, and especially the realized body, is imbued with a practitioner's religious attainment, even in the case enlightenment itself.

With this we may return to the Brahmāyu-sutta, with which we began our analysis. This text offered a remarkably grounded presentation of the Buddha's bodily perfection, highlighting his completely gentle and balanced use of his muscles and limbs. Yet there too, we sensed the metaphysical interpretation lurking in the background and rising to the surface in such statements as that the Buddha only begins walking with his right foot. In fact, the depiction of the Buddha's body we read comes after one of the major introductions of the doctrine of the 32 marks in the Nikāyas, serving to expand and bring it down to earth. While this approach clearly reveals an ingenious understanding of the Buddha's body, it also treads the fine line between the physical and the metaphysical, trying to tie the two together. See the following statement of the way the Buddha wears his robes, which comes a little below the passages we read:

The robe of the reverend Gotama is not too long or too short; it does not stick to his body and is not too loose; the wind does not blow the reverend Gotama's rope

\footnotetext{
78 DN I.77.6-10: so ... manomayam kāyam abhinimmānāya cittam abhinīharati abhininnāmeti. so imamhā kāyāa añãam kāyam abhinimmināti rūpim manomayạ̣ sabbañgapaccañim ahīnindriyam.

79 See for example in Radich (2007, chp. 3); Mrozik (2007, chp.4); Powers (2009, pp. 12-16).

80 A recent and interesting contribution to this line of analysis is McGovern (2016), who also manages to identify certain parallels between the list of the 32 marks and the 6th century C.E. Brahmanical source of the Brhatsamhitā.

81 By using this term in this way I intend a theorization that relies on elements beyond the empirical, which are taken to be no less, and perhaps more, real than empirical knowledge. I prefer the term metaphysical to spiritual.
} 
away from his body; and dust and dirt do not stick to the reverend Gotama's body. ${ }^{82}$

We can easily sense the texts swaying between physical and metaphysical interpretations. On the one hand, the Buddha wears his robes at the correct length and they are not too tight or too loose; on the other, the wind will not blow the robes away from his body, and we are told that dust, and apparently also the robe itself, cannot stick to it. Indeed, this last statement is taken directly from the presentation of the 32 marks, here quoted from earlier in the same text- "The reverend Gotama has exceedingly soft skin; because of his exceedingly soft skin, dirt and dust do not stick to his body."183

A body is not just a body. Much like a relic, it is imbued with a deeply metaphysical nature, carrying within it not only the moral acts of the past, but also its degree of realization. The truths it gives life to far exceed the physical and the empirical. The Buddha's body is pervaded by his awakened consciousness, and it consists of more than matter. Perhaps, however, it is our divide that causes us trouble to begin with. Perhaps, for early Buddhism, there was no clear distinction between the physical and the metaphysical, and each was seen as the natural expression of the other. It is not only that the Buddha's body is pregnant with metaphysical truths that are beyond the material; it is no less true that for this tradition, metaphysics is thoroughly embodied, so that the spiritual and material are different sides of the same coin. It is, thus, a completely natural fact that the Buddha possesses such an elegant and captivating body, given that his body is just as realized as his mind, and that it is thoroughly permeated by the truths he realized. ${ }^{84}$

Funding: This research received no external funding.

Conflicts of Interest: The author declares no conflict of interest.

\section{References}

Anālayo. 2003. Satipatthāna: The Direct Path to Realization. Birmingham: Windhorse Publications.

Anālayo. 2011. A Comparative Study of the Majjhima-Nikāya. Taipei: Dharma Drum Publishing Corporation, vol. $1+2$.

Anālayo. 2012. Excursions into the Thought-World of the Pāli Discourses. Onalaska: Pariyatti Press.

Arbel, Keren. 2017. Early Buddhist Meditation: The Four Jhānas as the Actualization of Insight. London and New York: Routledge.

Ben-David, Aviran. 2017. An Examination of the Concept of Liberation in the Sutta-pitaka of the Pāli Canon. Master's Thesis, The Hebrew University of Jerusalem, Jerusalem, Israel.

Bhikkhu Bodhi, and Bhikkhu Nānamoli, transs. 1995, The Middle Length Discourses of the Buddha: A New Translation of the Majjhima Nikaya. Boston: Wisdom Publications in Association with the Barre Center for Buddhist Studies.

Bronkhorst, Johannes. 1993. The Two Traditions of Meditation in Ancient India. Delhi: Motilal Banarsidass.

Bronkhorst, Johannes. 2009. Buddhist Teachings in India. Boston: Wisdom Publications.

Cabezón, José I. 2017. Sexuality in Classical South Asian Buddhism. Somerville: Wisdom Publications.

Collett, Alice. 2014. Women in Early Buddhism: Comparative Textual Studies. New York: Oxford University Press.

Collins, Stephen. 1997. The Body in Theravāda Buddhist Monasticism. In Religion and the Body. Edited by Sarah Coakley. Cambridge: Cambridge University Press.

de La Vallée Poussin, Louis. 1937. Musīla et Nārada. Mélanges Chinois et Boudhiques 5: 189-92.

Feldenkrais, Moshe. 1985. The Potent Self: A Guide to Spontaneity. Cambridge, Hagerstown, New York, Philadelphia, London, Mexico City, São Paolo, Singapore and Sydney: Harper \& Row.

Gallagher, Shaun. 2005. How the Body Shapes the Mind. New York: Exford University Press.

Gallagher, Shaun, and Dan Zahavi. 2008. The Phenomenological Mind: An Introduction to the Philosophy of Mind and Cognitive Science. London and New York: Routledge.

Gethin, Rupert M. L. 2001. The Buddhist Path to Awakening. Oxford: Oneworld. First Published 1992.

Gombrich, Richard F. 1996. How Buddhism Began. London and Atlantic Highlands: Athlone.

Grinshpon, Yohanan. 2002. Silence Unheard: Deathly Otherness in Pätañjala-Yoga. Albany: SUNY.

Gross, Rita. 1993. Buddhism after Patriarchy: A Feminist History, Analysis, and Reconstruction of Buddhism. Albany: SUNY.

82 MN II.139.20-25: na ca tassa bhoto gotamassa kāye cīvaram accukkatṭam hoti na ca accokkațtham, na ca kāyasmim allīnam na ca kāyasmā apakaț̣am; na ca tassa bhoto gotamassa kāyamhā vāto cìvaram apavahati; na ca tassa bhoto gotamassa kāye rajojallam upalimpati.

83 MN II.129.19-20: sukhumacchavi kho pana so bhavam gotamo. sukhumattā chaviyā rajojallạ̣ kāye na upalimpati.

84 I thank Amy Langenberg for illuminating remarks on an earlier version of this article, as well of the careful and insightful reading of the two anonymous reviewers assigned by the Journal. 
Gummer, Natalie. 2020. The Scandal of the Speaking Buddha: Performative Utterance and the Erotics of the Dharma. In Buddhist Literature as Philosophy, Buddhist Philosophy as Literature. Edited by Rafal K. Stepien. Albany: SUNY, pp. 197-229.

Gyatso, Janet. 2005. Sex. In Critical Terms for the Study of Buddhism. Edited by Donald Lopez. Chicago: University of Chicago Press, pp. 271-90.

Hamilton, Sue. 2003. Early Buddhism: A New Approach, the I of the Beholder. Great Britain: Curzon.

Harvey, Peter. 1995. The Selfless Mind: Personality, Consciousness and Nirvana in Early Buddhism. Richmond: Curzon.

Kieschnick, John. 2005. The Impact of Buddhism on Chinese Material Culture. Princeton: Princeton University Press.

Kuan, Tse-fu. 2008. Mindfulness in Early Buddhism: New Approaches through Psucgology and Textual Analysis of Pali, Chinese and Sanskrit Sources. London and New York: Routledge.

Langenberg, Amy Paris. 2017. Birth in Buddhism: The Suffering Fetus and Female Freedom. London and New York: Routledge.

Langenberg, Amy Paris. 2018. Buddhism and Sexuality. In The Oxford Handbook for Buddhist Ethics. Edited by Daniel Conzort and James Mark Shields. Oxford: Oxford University Press. [CrossRef]

Maneé, Joy. 1990. Categories of Sutta in the Pāli Nikāyas and their Implications for our Appreciation of the Buddhist Teaching and Literature. Journal of the Pali Text Society XV: 29-87.

Marino, Joseph. 2015. Cats with Flaming Tails: The Simile off the Fortified City in Pāli and Gāndhārī Sūtra Literature. Journal of the International Association of Buddhist Studies 38: 73-105.

McGovern, Nathan. 2016. On the Origins of the 32 Marks of a Great Man. Journal of the International Association of Buddhist Studies 39 : 207-47.

Merleau-Ponty, Maurice. 1962. Phenomenology of Perception. London: Routlegde and Kegan Paul.

Mrozik, Susanne. 2007. Virtuous Bodies: The Physical Dimensions of Morality in Buddhist Ethics. New York: Oxford University Press.

Powers, John. 2009. A Bull of a Man: Images of Masculinity, Sex, and the Body in Indian Buddhism. Cambridge and London: Harvard University Press.

Radich, Michael D. 2007. The Somatics of Liberation: Ideas about Embodiment in Buddhism from Its Origins to the Fifth Century C.E. Ph.D. dissertation, Harvard University, Cambridge, UK.

Salgado, Nirmala M. 2013. Buddhist Nuns and Gendered Practice: In Search of the Female Renunciate. New York: Oxford University Press.

Schmithausen, Lambert. 1981. On some Aspects or Theories of 'Liberating Insight' and 'Enlightenment' in Early Buddhism. In Studien zun Jainismus und Buddhismus: Gendenkschrift für Ludwig Alsdorg. Edited by Klaus Bruhn and Albrecht Wezler. Wiesbaden: Franz Steiner Verlag $\mathrm{GmbH}$.

Schopen, Gregory. 1997. Bones, Stones and Buddhist Monks: Collected Papers on the Archaeology, Epigraphy, and Texts of Monastic Buddhism in India. Honolulu: University of Hawai'i Press.

Seneviratne, Heraliwala L. 1978. Rituals of the Kandyan State. Cambridge: Cambridge University Press.

Shulman, Eviatar. 2010. “Mindful Wisdom: The Sati-pațthāna-sutta on Mindfulness, Memory and Liberation. History of Religions 49: 393-420. [CrossRef]

Shulman, Eviatar. 2014. Rethinking the Buddha: Early Buddhist Philosophy as Meditative Perception. Cambridge: Cambridge University Press.

Shulman, Eviatar. 2017a. Polyvalent Philosophy and Soteriology in Early Buddhism. Philosophy East and West 67: 864-86. [CrossRef]

Shulman, Eviatar. 2017b. The Buddha as the Pole of Existence, or the Flower of Cosmos. History of Religions 57: 164-96. [CrossRef]

Shulman, Eviatar. 2017c. The Early Discourses of the Buddha as Literature: Narrative Features in the Dīgha Nikāya. Journal of Religion 97: 360-87. [CrossRef]

Shulman, Eviatar. Forthcoming. Visions of the Buddha: Early Buddhist Philosophy as Meditative Perception. Cambridge: Cambridge University Press.

Skilling, Peter. 2005. Cutting Across Categories: The Ideology of Relics in Buddhism. Annual Report of the International Research Institute for Advanced Buddhology at Soka University 8: 269-322.

Sponberg, Alan. 1992. Attitudes Toward Women and the Feminine in Early Buddhism. In Buddhism, Sexuality, and Gender. Edited by José I. Cabezón. Albany: SUNY.

Strong, John S. 2004. Relics of the Buddha. Princeton: Princeton University Press.

Thompson, Evan. 2017. Waking, Dreaming, Being: Self and Consciousness in Neuroscience, Meditation and Philosophy. New York: Columbia University Press.

Varela, Fransisco. 1996. Neurophenomenology: A Methodological Remedy to the Hard Problem. Journal of Consciousness Studies 3: 330-49.

Vetter, Tilmann. 1988. The Ideas and Meditative Practices of Early Buddhism. Leiden, New York, KØbenhavn and Köln: E. J. Brill.

Wilson, Liz. 2012. Buddhism and Gender. In Buddhism in the Modern World. Edited by David McMahan. London and New York: Routledge, pp. 257-72. 